\title{
Digital Sport-Management Games and Their Contribution to Prospective Sport-Managers' Competence Development
}

\author{
Rolf Kretschmann \\ Department of Sport and Exercise Science, University of Stuttgart, Stuttgart, Germany \\ Email: rolf.kretschmann@inspo.uni-stuttgart.de
}

Received July $18^{\text {th }}, 2012$; revised August $20^{\text {th }}, 2012$; accepted September $2^{\text {nd }}, 2012$

\begin{abstract}
The immersive and engaging characteristics of digital games are leading current pedagogical discussions about digital media. Game scientists, (pedagogical) researches, and practitioners continue to attempt to embed digital games in pedagogical settings. They consider these games to be so called serious games. The idea of serious games is that a digital game is not only played for fun and entertainment, but to employ the specific game-play for serious learning processes and outcomes in a specific field of learning or work. Hence, the question arises, whether a digital sport-management game can assist prospective sport managers and students of sport management at the introduction to this complex field of work. To tackle the research question, it is necessary to investigate the profession of sport managers in "real" life and compare the game-play of a digital sport management game to them. Therefore, the best selling and most famous so-called commercial off-the-shelf (COTS) game FIFA Manager 09 by EA Sports is picked to be the subject of analysis. "Virtual" sport-manager competencies were compared to "real-world" sportmanager competencies to find any matching. As a result, there actually is a high congruence between sport-management competence-models and the digital game's game-play.
\end{abstract}

Keywords: Digital Sport Games; Game-Based Learning; Serious Games; Sport Computer Games; Sport Pedagogy; Sport Management; Transfer of Learning

\section{Introduction}

Football is undoubtedly one of the most popular fields of sport in the world. Among other things this is shown through its omnipresent appearance in global mass media and sport reporting. Almost anybody has got at least something to say about that sport. Thinking of one's wide circle of friends, one will surely find someone who is into football or at least has got an opinion on the specific action in this field of work and how professionals should act therein. This apparent need of outsiders to advise actors within a specific field (e.g., soccer/football, and other popular sports) can also be observed in the field of politics.

Being a sport manager is professionalized as being a politician. Higher education offers degrees in sport management, which even has become a distinct sub-discipline of sport science containing scientific theory, content and methodology. Therefore, studying sport management reveals the complex structure of the field of work in question, which may appear quite simple in every-day life.

At this point, digital games and the idea of using them as serious games come in. The idea of serious games is that a digital game is not only played for fun and entertainment, but to employ the specific game-play for serious learning processes and outcomes within a specific field of learning or work. Prensky (2001, 2006) developed a pedagogical framework for this idea, calling it digital game-based learning (DGBL).

Integrating sport management and digital games, the question arises, whether a digital sport management game can introduce prospective sport managers and students of sport management to this complex field.
To approach the research question, it is necessary to investigate the tasks of a sport manager in real life and compare the game-play and tasks of a digital sport management game to them. Therefore, the best selling and most famous so called commercial off-the-shelf (COTS) game among sport management games is picked to be the subject of analysis, namely FIFA Manager 09, developed and published by EA Sports. FIFA Manager 09 offers tasks and options, which are comparable in complexity to the scope of real world decision-making. The digital game therefore may be employed to foster transfer of learning (Gee, 2003).

The aim of the paper is to investigate whether playing a digital game might provide beneficial learning processes and outcomes. Is the digital game pedagogically worthy of consideration for being recognized for educating prospective sport managers?

For this purpose, the profession of a sport manager needs to be described to set the informational basis for argumentation. Thereafter, sport management games have to be defined, too. A following game-play analysis of FIFA Manager 09 intends to lead to an insight of the inner structure of this digital game. The results of this game-play analysis will allow a comparison of digital sport-manager competencies and "real" sport-manager competencies using sport management competence-models as comparison criteria. Experts, in this case, MA students of sport management will do the rating.

\section{Methods}

\section{The Profession of a Sport Manager}

Sport management is a relatively young academic discipline 


\section{R. KRETSCHMANN}

(Chalip, 2006). It is both a sub-discipline of sport science and business (and management) studies. Sport management refers to "all people, activities, businesses, and organizations involved in producing, facilitating, promoting, or organizing any product that is sport, fitness, and recreation related" (Pitts \& Stotlar, 2002: p. 4). "Sport management programs train people for management positions in such areas as college athletics, professional teams, fitness centers, recreational centers, coaching, officiating, marketing, youth organizations, and sporting goods manufacturing and retailing" (Lussier \& Kimball, 2009: p. 4).

Appenzeller and Lewis (2000) structure the fields of sport management into six parts: 1) human resource management; 2) program management; 3) marketing management; 4) facility and event management; and 5) legal management.

Further descriptions of the sport manager profession can also be found at Lussier and Kimball (2009): Sport managers have to deal with several resources: 1) human resources; 2) financial resources; 3) physical resources; and 4) informational resources. Sport managers need to have a set of skills: 1) technical skills; 2) people skills; 3) communication skills; 4) conceptual skills; and 5) decision-making-skills. Moreover, sport managers plan, organize, lead, and control, which correspond to the four (sport) management functions: 1) planning; 2) organizing; 3) leading; and 4) controlling.

Parks et al. (1988) modeled sport-management task-clusters which combine general sport management tasks with organization and information management. General sport management tasks show up in the fields: 1) marketing and sales; 2) correspondence; 3) public speaking; 4) community relations; and 5) record keeping. Special tasks emerge from organization and information management, Organization management tasks contain: 1) budgeting; 2) accounting; 3) coordination; 4) managing personnel; 5) managing facilities; 6) controlling; 7) directing; 8) evaluating; and 9) leading. Information management tasks contain: 1) writing; 2) selling; 3) working with media; 4) developing publications; 5) keeping game notes and statistics; 6) interviewing; 7) promoting; 8) advertising; and 9) fund-raising.

Hoff et al. (2007: p. 61) consider the following skills as necessary for success in sport management (according to Patterson \& Allen, 1996): "1) computer literacy in all types of technology; 2) flexibility and adaptability to handle ever- changing roles and management styles; 3 ) diversity in ability to function and work with people from a broad range of ages, cultures, and learning styles; 4) language skills-especially for the global marketplace; 5) team players - networking and negotiating skills a must; 6) learning skills and continuous reeducation; 7) personal career planning skills (self assessment, inner worth, current skills); 8) global awareness/orientation — knowledge of a country and region as well as the culture of the people there; 9) oral and written communication skills-become even more valuable as corporations flatten; 10) people must be self-starters; 11) self-comfort - the company no longer defines the worker; 12) strong ethical framework; 13) environmental scanning skills - knowing where your company is going, where the opportunities will be, see which direction to flex forward."

\section{Digital Sport-Management Games}

In general management (education) research, there is little emphasis on digital games to be found. Although role-playing games and board games are a usual way to train (prospective) managers (Corner et al., 2006; Faria, 1998; Salas et al., 2009;
Zwikael \& Gonen, 2007), digital games are hardly traceable. Traditional "analogue" simulations, (board) games, or roleplaying games are often transferred to an online version (Meisel \& Marx, 1999), but COTS games are of almost none interest so far.

However, there is evidence that the potential of digital games is recognized. Beck (2005 in Emerald Group Publishing Limited, 2004) highlights the decision-making and team-working skills impact of digital games on upcoming managers (Beck \& Wade, 2004). In addition, the shift to a more computer-savvy generation seems also to be recognized (Proserpio \& Gioia, 2007).

Consulting research literature on digital games, one will surprisingly notice that sport-management games like FIFA Manager 09 are not covered in-depth. Research on genre of digital sports-games is highly underrepresented. For instance, neither Wolf (2005) nor Laird and van Lent (2005) allude to sportmanagement games. Even Kayali and Purgathofer (2008), who deal with digital sports-games explicitly, do not tackle sportsmanagement games at all. Only Kretschmann (2008, 2010) dares to attempt a classification of digital sports-games and develops a competence model for digital sports-games. $\mathrm{He}$ differentiates between sport-simulation games, sport-arcade games, and sport-management games.

"Sports management games are to be placed in the category of role-playing games. The user (or player) assumes the leadership of a sports club or an athlete and has to deal with all the reality-based problems a person in that role has (e.g., economics and financials). Compared to sports simulations and sports arcade games, sports management games have almost real-life complexity but only from the view of a person in a leading position. They do not allow the user to intervene in the specific sports action 'on the court' by playing an athlete in certain situations. Here are some examples: Box Sport Manager (boxing), FIFA Manager 09 (soccer), Football Manager 09 (soccer), NFL Head Coach (American football)" (Kretschmann, 2010: p. 69).

Due to the fact that game developers update a sport-management game on a yearly basis, examples can be exchanged and updated when a new version of a certain game is published. Normally, the game's essential game-idea and game-play remains the same, only some features were added or revised.

\section{Game-Play Analysis of FIFA Manager 09}

The sub-genre of sport-management games has not been of much interest to game research yet, even though Becker (2007), Dondi et al. (2004), Gee (2003), and Mitchell and Savill-Smith (2004) focus on the pedagogical use of COTS computer and video games in general. They do not differentiate sharply between genres or even certain games or game series. Actually, Kirriemuir (2005) features certain COTS games, but did not examine a sport-management game. McFarlane et al. (2002) report positive learning outcomes and skill development by playing various digital games, including the sport-management game Championship Manager (football). Unfortunately, the game was merged with other games of different genres, so that the posited skill development cannot be attributed unambiguously to Championship Manager.

In the serious-games paradigm a sport-management game could be a good introduction to the field of work of prospective sport-managers. Game-play analysis of FIFA Manager 09 


\section{R. KRETSCHMANN}

should be a good start to test this hypothesis. Although the term game-play is ambiguous, one can state some (wide) definitions. Björk and Holopainen (2005: p. 3) define game-play as "the structures of player interaction with the game system and with other players in the game", while Rollings and Adams (2007: p. 201) consider "one or more causally linked series of challenges in a simulated environment" to define game-play. Integrating the described approaches, game-play analysis simply means an objective description of the possible actions that a player of a digital game has while acting within the game or gaming environment. Thus the following should serve as an informational input and map for non-players of FIFA Manager 09.

In FIFA Manager 09 the player assumes the role of the manager of a football club. The player can freely choose an avatar and its attributes as name or face. He or she has to decide between various international football clubs all over the world, considering whether to take a lower or higher league club. The FIFA Manager 09 license includes real names of football clubs and players. The game-play contains several areas of possible acting. Aside from optional informational slides and options for preferences, sounds, music, etc., the player can choose between four main categories: 1) team; 2) transfer; 3) club; and 4) career. Within each category one can find several sub-categories. For team the player can choose seven topics: 1) news centre; 2) calendar; 3) first team; 4) reserve team; 5) youth team; 6) training; and 7) dressing room chemistry. For transfers the player can choose between five topics: 1) contracts; 2) staff; 3) transfer market; 4) cooperation; and 5) scouting. For club the player can choose between seven topics: 1) financial status; 2) stadium, 3) club facilities; 4) merchandising; 5) ticketing; 6) sponsoring; and 7) achievements. For career the player can choose between five topics: 1) my career; 2) personal life; 3) watch other matches; and 4) career options.

The high degree of complexity of possible decision-making can be illustrated by regarding decision-making options in the exemplarily selected field team, specifically in the sub-category dressing room chemistry. In order to keep it brief, only this one example of game-play analysis with FIFA Manager 09 will be given.

Confronted with the dressing room chemistry screen, the player has several options to choose. He or she can talk to each football player or the whole team and/or can make promises. Depending on the position (e.g., goalkeeper or striker) the player can choose up to ten different sentences to say to a football player (e.g., "You're in fantastic shape."). Additionally, the he or she can make promises to each football player (e.g., "You are a first eleven player." or "Don't expect to play.") and "special promises" (e.g., "Next year I'll make you captain."). On "team promises" the player can act within four areas: 1) season objectives (e.g., "We'll win the championship!"); 2) team (e.g., "Anyone who isn't fit doesn't play."); 3) infrastructure (e.g., "The stadium will be extended."); and 4) reserves (e.g., "We'll win promotion this season!"). The player's decisions have an impact on the mood and performance of each football player and the whole team. Thus, the player's decision-making process gets immediate feedback by the digital game.

The selected example of dressing room chemistry stands for more than 100 decision-making alternatives. According to all the sub-categories within the four main categories the number of possible decision-making options in the whole game increases exponentially. The player can definitely spend hours just for a first superficial adjustment on demanded decision-making options in the game. Fine adjustment while playing a game season will take additional time and careful consideration as well. The combination of all possible (and therefore clickable) decision-making options in FIFA Manager 09 reaches almost real-life complexity, covering almost every relevant field of sport-management decision-making.

For further information on the game, consultation of game reviews is approved (e.g., Clifford, 2009; Korda, 2009). Professional computer and video game review-journals (printed or online) can be a worthwhile source for information about a game's game-play from an experienced expert-gamer perspective.

\section{Rating Strategy}

The intended comparison of digital sport-management and "real" sport-management needs criteria and a model to stick to. Therefore, the theoretical background of academic sport-management will be coupled with the game-play analysis. Due to practicality and manageability the desktop-menu (sub-) categories of FIFA Manager 09 will serve as the basic framework, into which the models by Lussier and Kimball (2009), Parks et al. (1988), and Hoff et al. (2007) are integrated. Knowing the game and its game-play well enough, it seems relatively easy to scan through the basic framework of FIFA Manager 09 and check whether an aspect of the particular sport-management model matches or not.

To exclude a personal, individual perspective by a single rater who might be biased by previous knowledge and prejudices, three different raters analyzed FIFA Manger 09's gameplay. A matching of a category is only reported if at least two raters identify a positive matching in the particular model.

All raters were students in a MA program for sport management and had experience both in playing digital sport-management games and "real" sport-managing through internships in local first-league football clubs. Their career aspirations were to finally be a professional sport manager in a professional football club. As it is almost impossible to find sport managers of first-league football clubs who belong to the so-called "digital natives" (Prensky, 2001), are therefore socialized by digital games, and have the needed media literacy and academic background to attend in this kind of study, the focus group of MA sport management students is a realistic one. Furthermore, it won't be easy to find current elite sport managers who have experience in playing FIFA Manager 09.

The selected students are the closest focus group to professional sport managers that was available because internships indicate a likely successful entering to the career in question (Cunningham et al., 2005). The low number of raters was the result of a low number of students of the MA program that fulfilled the three conditions of: 1) having the aspiration in becoming a sport manager of an elite football club; 2) having already accomplished an internship at one of the targeted clubs; and 3) having experience in computer and video games, especially in the FIFA Manager franchise.

The raters were briefly introduced into the three competence models: Lussier and Kimball (2009), Hoff et al. (2007), and Parks et al. (1988). They should match their gaming experience (all raters have completed at least three seasons within the game) with the selected competence models. The raters had to fill out empty matrices (Tables 1-3) with a cross when they thought a match occurs. The instruction was: "Match the game-play of 


\section{R. KRETSCHMANN}

Table 1.

FIFA Manager 09 vs. Lussier \& Kimbal (2009).

\begin{tabular}{|c|c|c|c|c|c|}
\hline & & Planning & Organizing & Leading & Controlling \\
\hline \multirow{7}{*}{ Team } & News centre & & & & $\mathrm{x}$ \\
\hline & Calendar & $\mathrm{x}$ & & & $\mathrm{x}$ \\
\hline & First team & $\mathrm{x}$ & $\mathrm{x}$ & $\mathrm{x}$ & $\mathrm{x}$ \\
\hline & Reserve team & $\mathrm{x}$ & $\mathrm{x}$ & $\mathrm{x}$ & $\mathrm{x}$ \\
\hline & Youth team & $\mathrm{x}$ & $\mathrm{x}$ & $\mathrm{x}$ & $\mathrm{x}$ \\
\hline & Training & $\mathrm{x}$ & $\mathrm{x}$ & $\mathrm{x}$ & $\mathrm{x}$ \\
\hline & $\begin{array}{l}\text { Dressing room } \\
\text { chemistry }\end{array}$ & $\mathrm{x}$ & & $\mathrm{x}$ & $\mathrm{x}$ \\
\hline \multirow{5}{*}{ Transfers } & Contracts & $\mathrm{x}$ & & & $\mathrm{x}$ \\
\hline & Staff & $\mathrm{x}$ & $\mathrm{x}$ & $\mathrm{x}$ & $\mathrm{x}$ \\
\hline & $\begin{array}{l}\text { Transfer } \\
\text { market }\end{array}$ & $\mathrm{x}$ & $\mathrm{x}$ & $\mathrm{x}$ & $\mathrm{x}$ \\
\hline & Cooperation & $\mathrm{x}$ & $\mathrm{x}$ & $\mathrm{x}$ & $\mathrm{x}$ \\
\hline & Scouting & $\mathrm{x}$ & $\mathrm{x}$ & $\mathrm{x}$ & $\mathrm{x}$ \\
\hline \multirow{7}{*}{ Club } & $\begin{array}{l}\text { Financial } \\
\text { status }\end{array}$ & $\mathrm{x}$ & $\mathrm{x}$ & $\mathrm{x}$ & $\mathrm{x}$ \\
\hline & Stadium & $\mathrm{x}$ & $\mathrm{x}$ & $\mathrm{x}$ & $\mathrm{x}$ \\
\hline & Club facilities & $\mathrm{x}$ & $\mathrm{x}$ & $\mathrm{x}$ & $\mathrm{x}$ \\
\hline & Merchandising & $\mathrm{x}$ & $\mathrm{x}$ & $\mathrm{x}$ & $\mathrm{x}$ \\
\hline & Ticketing & $\mathrm{x}$ & $\mathrm{x}$ & $\mathrm{x}$ & $\mathrm{x}$ \\
\hline & Sponsoring & $\mathrm{x}$ & $\mathrm{x}$ & $\mathrm{x}$ & $\mathrm{x}$ \\
\hline & Achievements & $\mathrm{x}$ & & & $\mathrm{x}$ \\
\hline \multirow{4}{*}{ Career } & My career & $\mathrm{x}$ & & & $\mathrm{x}$ \\
\hline & Personal life & $\mathrm{x}$ & $\mathrm{x}$ & $\mathrm{x}$ & $\mathrm{x}$ \\
\hline & $\begin{array}{l}\text { Watch other } \\
\text { matches }\end{array}$ & $\mathrm{x}$ & & & \\
\hline & Career options & $\mathrm{x}$ & & & $\mathrm{x}$ \\
\hline
\end{tabular}

FIFA Manager with the selected sport-manager competencemodels! If you think the game-play can foster a particular models' competence dimension make a cross according to the game's clickable structure! If you are not sure you can re-play the game to experience the game-play in question once more." Raters had access to the game while they were given the task.

\section{Results}

The matching decisions of the three raters (A, B, and C) were verified by determining inter-rater reliability using Cohen's kappa ( $\kappa)$ (Cohen, 1960). Coding consistency for rater A and B was $\kappa=0.91$, between rater $A$ and $C$, it was $\kappa=0.94$, and between rater $\mathrm{B}$ and $\mathrm{C}$, it was $\kappa=0.89$. Kappa values of 0.4 to 0.6 are characterized as fair, 0.6 to 0.75 as good, and over 0.75 as excellent (Bakeman \& Gottman, 1997; Fleiss, 1981). Therefore, inter-rater reliability can be considered excellent and very high for the matching decisions.
The model by Lussier and Kimball (2009) reaches almost a total match (Table 1). The model by Parks et al. (1988) leaves some aspects untouched (language skills, oral and written communication skills, and self-starters) (Table 2). Moreover, the model by Hoff et al. (2007) shows negative matches for writing and interviewing, as it also produces the lowest number of matches compared to the other models (Table 3).

In overview, only a few categories of the selected models are not covered by FIFA Manager 09.

\section{Discussion}

The negative match of the Parks et al. (1988) model can easily be explained by the fact that face-to-face conversations with human beings are missing. The game-play of FIFA Manager 09 does not simulate complex human conversational interaction. Hence, language and communication skills are not fostered because FIFA Manager 09 does not allow the player to have complex written or oral communication. The negative match of self-starters does not surprise much, due to the fact that FIFA Manager 09 is a computer game and therefore unable to set the start-up for a real-world sport-management career.

The negative matches for writing and interviewing of the model by Hoff et al. (2007) can be explained similarly to the Parks et al. (1988) model; equal reasons of game-play and missing human interaction cause these negative matches.

The fact that the Parks et al. (1988) model produces the lowest number of matches compared to the other models can be explained by the inner complexity of the model. Numerous sub-categories are evidence of a specialized and highly differentiated model. Matching one complex model with another complex model, as the framework of FIFA Manager 09 surely is, naturally leads to a small intersection. Thus, the overall matching rate can't be as high compared to less complex models. Moreover, quantity can't be the only measure for the presented matching process. Some specialized aspects of the Hoff et al. model are important for only some specialized sport-manager processes. For instance, managing facilities is so specialized that is has got nothing to do with the FIFA Manger 09 categories team, transfers, and career. These specialized aspects indicate a quality match; that means that there actually is a high matching rate, although quantitative analysis displays a lower matching one.

According the high number of matches, the intersection of digital sport management and "real" sport management is truly obvious and therefore strengthened by academic theory. This means that a linkage between certain competences of "scientific theory" and the game-play can be confirmed by rating results. Thus, transfer of learning (Gee, 2003) may be fostered by the digital game.

In sum, sport-management games are of use for prospective sport managers. FIFA Manager 09 might be employed for serious learning processes and outcomes, which have a large amount of skills and tasks in common with "real" sport-management and managers. Nonetheless, there is "open space" that is not covered by the sport-management game due to a lack of face-to-face interaction and physical experience within the "real" world.

Sport-management games, exemplarily FIFA Manager 09, can give an overview on the field of work in question to sportmanagement students. These games, which can actually be seen as serious games, can serve as an exploratory introduction 


\section{R. KRETSCHMANN}

Table 2.

FIFA Manager 09 vs Parks et al. (1988).

\begin{tabular}{|c|c|c|c|c|c|c|c|c|c|c|c|c|c|c|}
\hline & & 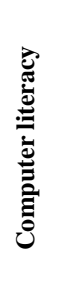 & 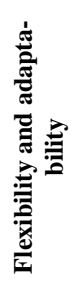 & 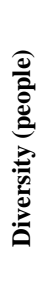 & 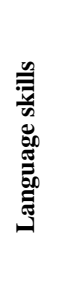 & 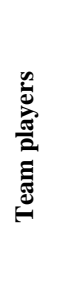 & 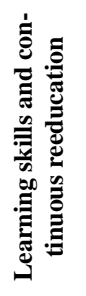 & 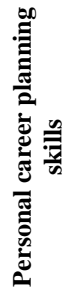 & 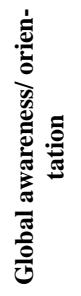 & 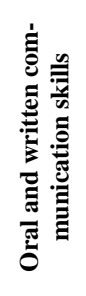 & 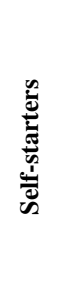 & 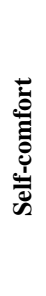 & 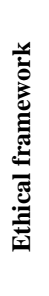 & 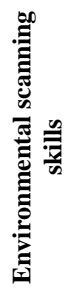 \\
\hline \multirow{7}{*}{ Team } & News centre & $\mathrm{x}$ & $\mathrm{x}$ & & & & $\mathrm{x}$ & & $\mathrm{x}$ & & & & & $\mathrm{x}$ \\
\hline & Calendar & $\mathrm{x}$ & $\mathrm{x}$ & & & & $\mathrm{x}$ & & $\mathrm{x}$ & & & $\mathrm{x}$ & & $\mathrm{x}$ \\
\hline & First team & $\mathrm{x}$ & $\mathrm{x}$ & & & & $\mathrm{x}$ & & & & & & & \\
\hline & Reserve team & $\mathrm{x}$ & $\mathrm{x}$ & & & & $\mathrm{x}$ & & & & & & $\mathrm{x}$ & \\
\hline & Youth team & $\mathrm{x}$ & $\mathrm{x}$ & & & & $\mathrm{x}$ & & & & & & $\mathrm{x}$ & \\
\hline & Training & $\mathrm{x}$ & $\mathrm{x}$ & & & & $\mathrm{x}$ & & & & & & & \\
\hline & Dressing room chemistry & $\mathrm{x}$ & $\mathrm{x}$ & $\mathrm{x}$ & & & $\mathrm{x}$ & & & & & & $\mathrm{x}$ & \\
\hline \multirow{5}{*}{ Transfers } & Contracts & $\mathrm{x}$ & $\mathrm{x}$ & $\mathrm{x}$ & & & $\mathrm{x}$ & & $\mathrm{x}$ & & & & $\mathrm{x}$ & \\
\hline & Staff & $\mathrm{x}$ & $\mathrm{x}$ & & & & $\mathrm{x}$ & & & & & $\mathrm{x}$ & $\mathrm{x}$ & \\
\hline & Transfer market & $\mathrm{x}$ & $\mathrm{x}$ & $\mathrm{x}$ & & & $\mathrm{x}$ & & $\mathrm{x}$ & & & & & \\
\hline & Cooperation & $\mathrm{x}$ & $\mathrm{x}$ & $\mathrm{x}$ & & $\mathrm{x}$ & $\mathrm{x}$ & & $\mathrm{x}$ & & & & $\mathrm{x}$ & \\
\hline & Scouting & $\mathrm{x}$ & $\mathrm{x}$ & & & & $\mathrm{x}$ & & $\mathrm{x}$ & & & & & \\
\hline \multirow{7}{*}{ Club } & Financial status & $\mathrm{x}$ & $\mathrm{x}$ & & & & $\mathrm{x}$ & & & & & & & $\mathrm{x}$ \\
\hline & Stadium & $\mathrm{x}$ & $\mathrm{x}$ & & & & $\mathrm{x}$ & & & & & & & $\mathrm{x}$ \\
\hline & Club facilities & $\mathrm{x}$ & $\mathrm{x}$ & & & & $\mathrm{x}$ & & & & & & & $\mathrm{x}$ \\
\hline & Merchandising & $\mathrm{x}$ & $\mathrm{x}$ & & & & $\mathrm{x}$ & & $\mathrm{x}$ & & & & & $\mathrm{x}$ \\
\hline & Ticketing & $\mathrm{x}$ & $\mathrm{x}$ & & & & $\mathrm{x}$ & & & & & & & $\mathrm{x}$ \\
\hline & Sponsoring & $\mathrm{x}$ & $\mathrm{x}$ & & & $\mathrm{x}$ & $\mathrm{x}$ & & $\mathrm{x}$ & & & & & $\mathrm{x}$ \\
\hline & Achievements & $\mathrm{x}$ & $\mathrm{x}$ & & & & $\mathrm{x}$ & & $\mathrm{x}$ & & & & & $\mathrm{x}$ \\
\hline \multirow{4}{*}{ Career } & My career & $\mathrm{x}$ & $\mathrm{x}$ & & & & $\mathrm{x}$ & $\mathrm{x}$ & $\mathrm{x}$ & & & & & \\
\hline & Personal life & $\mathrm{x}$ & $\mathrm{x}$ & & & & $\mathrm{x}$ & $\mathrm{x}$ & $\mathrm{x}$ & & & & & \\
\hline & Watch other matches & $\mathrm{x}$ & $\mathrm{x}$ & & & & $\mathrm{x}$ & $\mathrm{x}$ & $\mathrm{x}$ & & & & & \\
\hline & Career options & $\mathrm{x}$ & $\mathrm{x}$ & & & & $\mathrm{x}$ & $\mathrm{x}$ & $\mathrm{x}$ & & & & & \\
\hline
\end{tabular}

to critical thinking and cybernetic basics of the dynamic sportmanagement processes and the profession of a sport manager in a professional sport club, namely a football club.

After re-considering the educational purpose and initial idea of developing sport-manager competences, further thinking will probably lead to the question "What type of manager?" And this might lead to a possible answer when considering the manager-types model by Lussier and Kimball (2009): 1) marketing manager; 2) operations manager; 3) finance manager; and 4) human resource manager (Figure 1).

Following this thought, game developers may in the future focus on games which only feature a certain type of sport ma- nager. Specialization in terms of a special training for certain manager types might be the result of this development. On the other hand, future sport-manager training-concepts might build on digital sport-management games with a broad focus that cover all manager tasks and types in general. In this case, sport-management games, which deal with a certain manager type only, might be used for specialized training in the training program for the selected manager type.

However, FIFA Manager 09 by EA Sports is not the only product in this sub-genre relating to football. Football Manager 09 by Sega is a serious competitor on the market place (Clifford, 2009; Hassoun, 2008). Football Manager 09's game-play and 
Table 3.

FIFA Manager 09 vs Hoff et al. (2007).

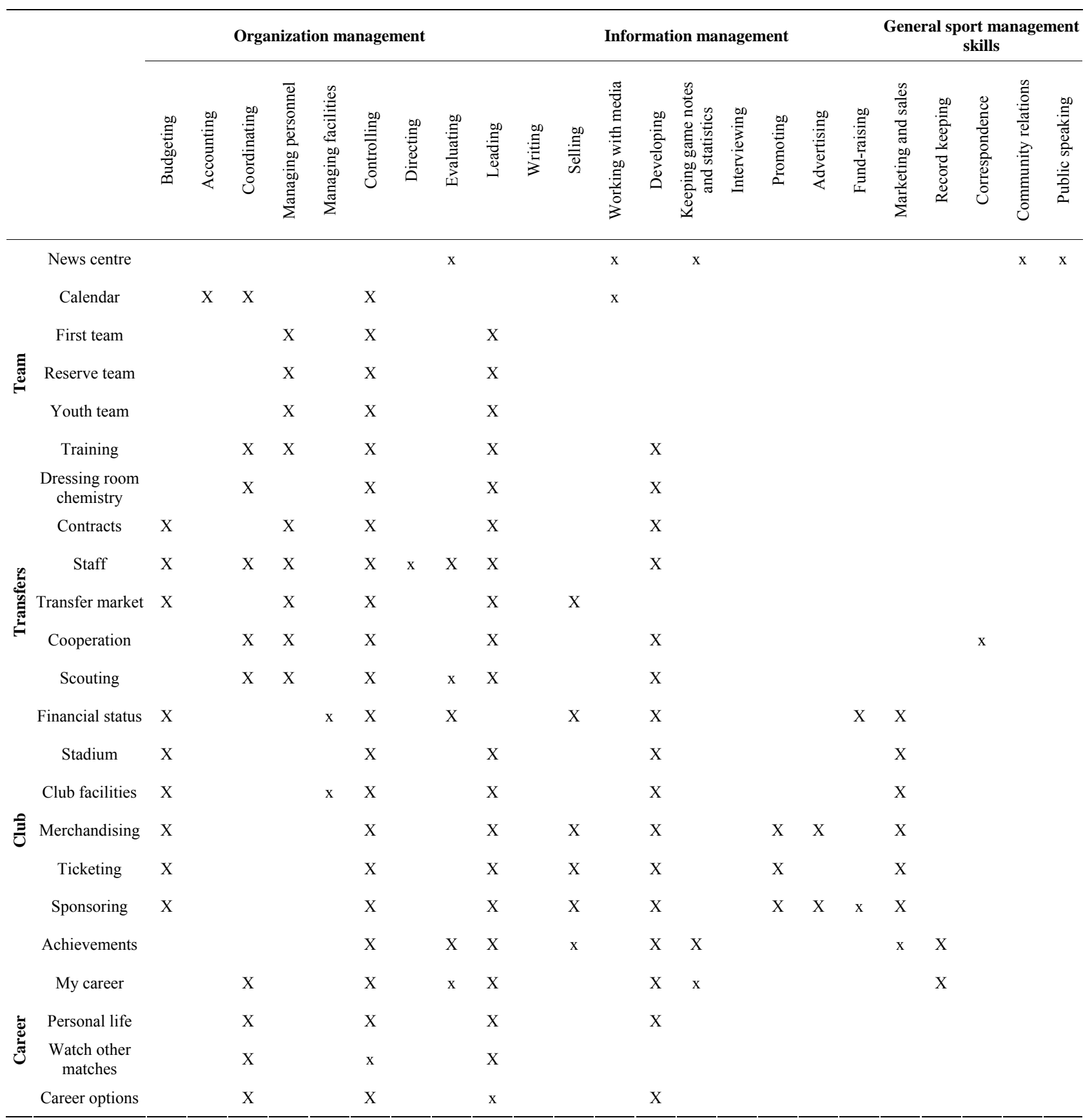

design differ from FIFA Manager 09 and could possibly lead to different results when using the same theoretical framework presented in this paper. Even other sport-management games, featuring different sports, could lead to different case studies due to specific game-design and game-play.

Further research might continue with an in-depth game-play analysis and might even change the point of view to "real" sport-management as a starting point and basic framework, instead of using "virtual" sport-management as the initial point for investigation. Furthermore, empirical data in quasi-experimental settings are recommended as well. These studies might compare prospective sport-manager learning-groups using sportmanagement games and "traditional" educational methods learning-groups. In this case, curriculum development is highly inconsistent. Therefore, curriculum development should integrate digital sport-management games sensibly. The original digital game-based learning approach by Prensky $(2001,2006)$ might serve as initial point.

Switching the viewpoint from sport managers to players, "perhaps Football Manager stimulates them to think about tactics and the responsibilities of a coach - the psychological aspects of managing players. It gives them an early insight, a 


\section{R. KRETSCHMANN}

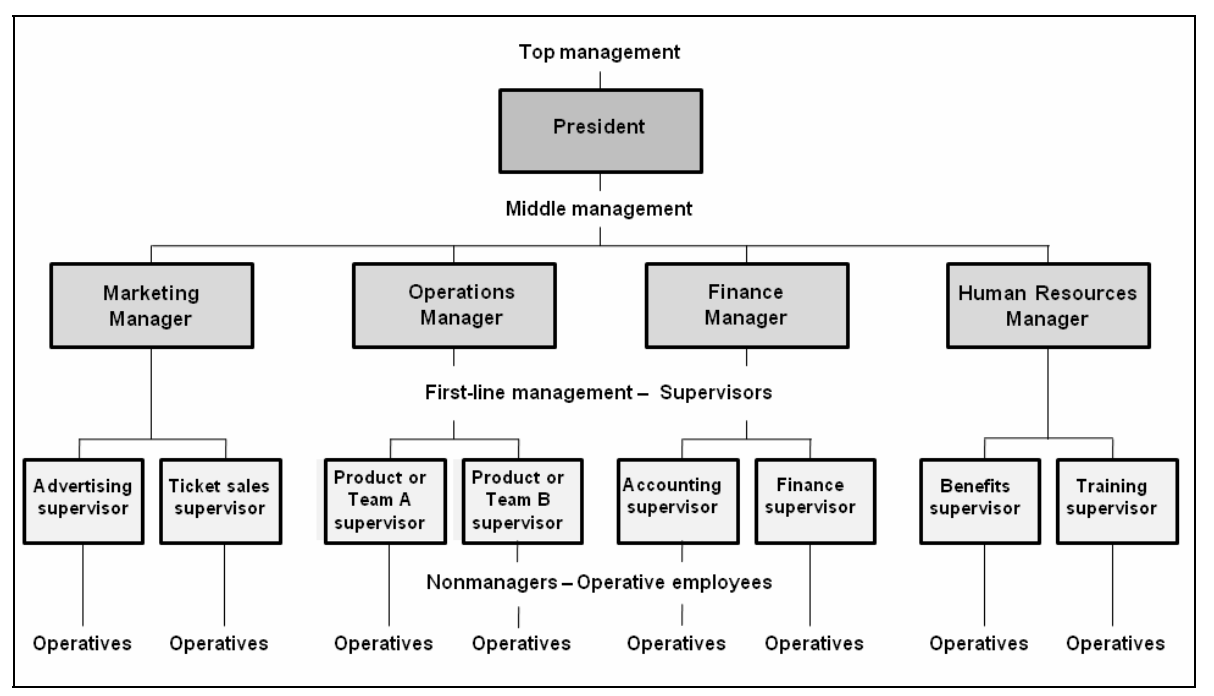

Figure 1.

Types of sport managers (adjusted from Lussier \& Kimball, 2009: p. 14).

different perspective on the sport" (Cox in Stuart, 2011). Therefore the DGBL approach might be applicable to all involved individuals in the action-research field football.

Nonetheless, a qualified educator is needed that is able to guide the prospective sport manager through the digital game's game-play properly. Not much focus is laid on the aspect of training the trainer so far (Peterson et al., 2008). A concept for a curriculum relating to trainers for digital sport-manager games that specializes on the learning-facilitator role is still in need to be developed.

Looking closer at factual typical sport manager careers of elite professional football clubs, it may appear as if a professional football career as a player is essential and necessary for entering the manager job (Carter, 2006). Therefore, alumni having degrees from colleges and universities might experience difficulties in competing against former athletes without college education. Regarding the increase in professionalization of the business it becomes apparent that "competition is so fierce for these jobs that a good education is extremely helpful" (Field, 2010: p. 27). Integrating innovative technology and teaching into educational curriculums therefore makes perfect sense.

As there are country-specific differences in job requirements, duties, and reality as well as in professional sport (manager) careers (Thibault, 2009), curriculum development and educational concepts for prospective sport managers may differ, of course. Gender issues and biases should also be considered, as highly ranked established (sport) manager positions are hard to access by women (Humberstone, 2009).

\section{Conclusion}

In conclusion, FIFA Manager 09, as a representative of digital sport-management games, offers a sensible introduction to the field of work of sport management and associated work. However, scientific evaluation of future didactical scenarios integrating sport-management games is needed. The digital game is only meant to be an assistant embedded in pedagogical arrangements that can't replace "real" experience with being a "real" sport manager acting in the "real" world. Research in this field is almost not existent, even though of utmost importance.
Researchers, educators, and game designers will need to cooperate to tackle its future challenges (Rousseau \& McCarthy, 2007).

\section{REFERENCES}

Appenzeller, H., \& Lewis, G. (2000). Successful sport management (2nd ed.). Durham, NC: Carolina Academic Press.

Bakeman, R., \& Gottman, J. M. (1997). Observing interaction. An introduction to sequential analysis. Cambridge, MA: Cambridge University Press. doi:10.1017/CBO9780511527685

Beck, J. C., \& Wade, M. (2005). Got game. How the gamer generation is reshaping business forever. Boston, MA: Harvard Business School Press.

Becker, K. (2007). Pedagogy in commercial video games. In D. Gibson, C. Adrich, \& M. Prensky (Eds.), Games and simulations in online learning. Research and development frameworks (pp. 21-47). Hershey, PA: Information Science Publishing.

Björk, S., \& Holopainen, J. (2005). Patterns in game design. Hingham, MA: Charles River Media.

Carter, N. (2006). The football manager. A history. London: Routledge.

Chalip, L. (2006). Toward a distinctive sport discipline. Journal of Sport Management, 20, 1-21.

Clifford, G. (2009). FIFA manager 09 review (PC). Can EA sports' offering challenge FOOTBALL manager for this year's title? URL (last checked 30 September 2010).

http://pc.boomtown.net/en_uk/articles/art.view.php?id=17418

Cohen, J. (1960). A coefficient of agreement for nominal scales. Educational and Psychological Measurement, 20, 37-46. doi:10.1177/001316446002000104

Corner, P. D., Bowden, S., Clark, D., Collins, E., Gibb, J., Kearins, K., \& Pavlovich, K. (2006). Grounded learning from a strategy case competition. Journal of Management Education, 30, 431-454. doi:10.1177/1052562905277789

Cunningham, G. B., Sagas, M., Dixon, M., Kent, A., \& Turner, B. A. (2005). Anticipated career satisfaction, affective occupational commitment, and intentions to enter the sport management profession. Journal of Sport Management, 19, 43-57.

Dondi, C., Edvinsson, B., \& Moretti, M. (2004). Why choose a game for improving learning and teaching processes? In M. Pivec, A. Koubek, \& C. Dondi (Eds.), Guidelines for game-based learning (pp. 20-76). Lengerich: Pabst Science Publishing.

Field, S. (2010). Career opportunities in the sports industry (4th ed.). New York: Ferguson. 


\section{R. KRETSCHMANN}

Fleiss, J. L. (1981). Statistical methods for rates and proportions. New York: Wiley.

Gee, J. P. (2003). What video-games have to teach us about learning and literacy. New York: Palgrave Macmillan.

Hassoun, R. (2008). Football manager 2009 review. URL (last checked 30 September 2010).

http://www.megamers.com/pc/review.php?game_category=2\&article id $=3407$

Hoff, K. S., Kroll, J., \& Fletcher, C. (2007). Developing a professional perspective. In J. B. Parks, J. Quarterman, \& L. Thibault (Eds.), Contemporary sport management (pp. 27-46). Champaign, IL: Human Kinetics.

Kayali, F., \& Purgathofer, P. (2008). Two halves of play. Simulation versus abstraction and transformation in sports videogames design. Journal for Computer Game Culture, 2, 105-127.

http://www.eludamos.org/index.php/eludamos/article/view/24/44

Kirriemuir, J. (2005). A survey of cots games used in education. URL (last checked 30 September 2010).

http://www.bris.ac.uk/education/research/networks/gern/gdc05.ppt

Korda, M. (2009). FIFA manager 09. URL (last checked 30 September 2010).

http://www.eurogamer.net/articles/fifa-manager-09-review?page=1

Kretschmann, R. (2008). Development of competencies by playing digital sports-games! Proceedings of the 2nd European Conference on Games-Based Learning, Reading, NJ: Academic Publishing Limited.

Kretschmann, R. (2010). Developing competencies by playing digital sports-games. US-China Education Review, 7, 67-75.

Laird, J. E., \& van Lent, M. (2005). The role of artificial intellegence in computer game genres. In J. Raessens, \& F. Goldstein (Eds.), Handbook of computer game studies (pp. 205-218). Cambridge, MA: MIT Press.

Lussier, R. N., \& Kimball, D. C. (2009). Applied sport management skills. Champaign, IL: Human Kinetics.

McFarlane, A., Sparrowhawk, A., \& Heald, Y. (2002). Report on the educational use of games. TEEM (teachers evaluating educational multimedia). URL (last checked 30 September 2010). http://www.teem.org.uk/publications/teem gamesined full.pdf

Meisel, S., \& Marx, B. (1999). Screen to screen versus face to face: Experiencing the differences in management education. Journal of Management Education, 23, 719-731. doi:10.1177/105256299902300609

Mitchell, A., \& Savill-Smith, C. (2004). The use of computer and video games for learning: A review of the literature. Learning and skills development agency. URL (last checked 30 September 2010). http://www.lsda.org.uk/files/PDF/1529.pdf

Parks, J. B., Chopra, P. S., Quain, R. J., \& Alguindigue, I. E. (1988).
ExSport I: An expert system for sport management career counseling. Journal of Research on Computing in Education, 21, 196-209.

Patterson, V., \& Allen, C. (1996). Occupational outlook overview: Where will the jobs be in 2005? Journal of Career Planning and Employment, 56, 32-35.

Peterson, R., Verenikina, I., \& Herrington, J. (2008). Standards for educational, edutainment, and developmentally beneficial computer games. Proceedings of World Conference on Educational Multimedia, Hypermedia and Telecommunications 2008, Chesapeake, VA: AACE.

Pitts, B. G., \& Stotlar, D. K. (2002). Fundamentals of sport marketing (2nd ed.). Morgantown, WV: Fitness Information Technology.

Prensky, M. (2001). Digital game-based learning. London: McGraw Hill.

Prensky, M. (2006). Don't bother me, Mom-I'm learning. How computer and video games are preparing your kids for 21st century success-And how you can help! Saint Paul, MN: Paragon House.

Proserpio, L., \& Gioia, D. A. (2007). Teaching the virtual generation. Academy of Management Learning \& Education, 6, 69-80. doi:10.5465/AMLE.2007.24401703

Rollings, A., \& Adams, E. (2007). Fundamentals of game design. Upper Saddle River, NJ: Pearson Prentice Hall.

Rousseau, D. M., \& McCarthy, S. (2007). Evidence-based management: educating managers from an evidence-based perspective. Academy of Management Learning \& Education, 6, 94-101. doi:10.5465/AMLE.2007.24401705

Salas, E., Wildman, J., \& Piccolo, R. (2009). Using simulation-based training to enhance management education. Management: Educating managers from an evidence-based perspective. Academy of Management Learning \& Education, 8, 559-573. doi:10.5465/AMLE.2009.47785474

Stuart, K. (2011). Football manager and the future of the beautiful game. Football manager developer sports interactive is investing in grassroots football-Is it shrewd marketing, genuine altruism or a bit of both? URL (last checked 30 September 2011).

http://www.guardian.co.uk/technology/gamesblog/2011/feb/21/footb all-manager-sports-interactive

Thibault, L. (2009). Globalization of sport: An inconvenient truth Journal of Sport Management, 23, 1-20.

Wolf, M. J. P. (2005). Genre and the video game. In J. Raessens, \& F. Goldstein (Eds.), Handbook of computer game studies (pp. 193-204). Cambridge, MA: MIT Press.

Zwikael, O., \& Gonen, A. (2007). Project execution game (PEG): Training towards managing unexpected events. Journal of European Industrial Training, 31, 495-512. 